\title{
Determining knowledge and willingness regarding stem cell donation among health science students: A cross-sectional study
}

\author{
(D) Damla Bayrak ${ }^{1}$, (1) Fatma İlknur Çınar² \\ ${ }^{1}$ Cankiri Karatekin University Faculty of Health Sciences, Department of Nursing, Cankiri, Turkey \\ 2University of Health Sciences Turkey, Gülhane Faculty of Nursing, Department of Internal Medicine Nursing, Ankara, Turkey
}

Date submitted:

25.03.2021

Date accepted:

12.06.2021

Online publication date: 15.03.2022

\section{Corresponding Author:}

Damla Bayrak, RN, MSc,

Cankiri Karatekin University Faculty

of Health Sciences, Department of

Nursing, Cankiri, Turkey

damlabayrak@karatekin.edu.tr

\section{ORCID:}

orcid.org/0000-0003-4419-1753

Keywords: Stem cell donation, potential stem cell donors, knowledge, willingness, barriers, incentives

Presented in: This study was presented at the $1^{\text {st }}$ International $2^{\text {nd }}$ National Oncology Nursing Congress on December 4-6, 2019, in Ankara as an oral presentation and was published in this congress book as an abstract.

\begin{abstract}
Aims: This study evaluated health science students' knowledge of stem cell donation, their willingness to become potential stem cell donors, and their perceived incentives and barriers to becoming potential stem cell donors.
\end{abstract}

Methods: This cross-sectional study was conducted in the faculty of health sciences of a university in Turkey. Data were collected using a questionnaire administered to health science students enrolled in the department(s) of child development, health management, midwifery, nursing, nutrition and dietetics, and physiotherapy and rehabilitation in October 2019.

Results: The sample included 541 students (80.8\% women) with a mean age of $19.70 \pm 1.52$ years. Most (80.8\%) of the students stated that they did not know what stem cell donation is. Of those who knew what stem cell donation is $(n=104), 5.8 \%$ reported that they were registered as potential stem cell donors, and $68.3 \%$ stated that they would like to be a potential stem cell donor. The most common reason for wanting to be a potential stem cell donor was the belief that the donation saves lives ( $n=71,83.1 \%$ ), and the most common reason for unwillingness or indecision about being a stem cell donor was the belief that there may be side effects ( $n=33$, 57.6\%).

Conclusions: We determined that most health science students did not know what stem cell donation is. Moreover, a large proportion of the students who knew about the stem cell donation expressed willingness to become potential stem cell donors, but very few of them were registered with the stem cell bank.

\section{Introduction}

Hematopoietic stem cell transplantation (HSCT) is an effective and life-saving method in treating many malignant and nonmalignant diseases. HSCT is classified as allogeneic, syngeneic, or autologous. Allogeneic transplantation is performed using stem cells obtained from a donor whose human leukocyte antigens (HLA) are compatible with those of the recipient (1). A factor limiting the applicability of this treatment is the low rate of HLA-compatible related donors (2). If there is no related match, allogeneic transplantation can also be performed from HLA-compatible unrelated donors (1). However, one of the main obstacles to this is the lack of potential unrelated bone marrow donors (3). 
There are three stem cell banks in Turkey where volunteer potential stem cell donors are registered. These stem cell banks organize recruitment drives to increase the number of volunteer donors (4). Having more donors increases the likelihood of finding an HLA-compatible donor, resulting in more transplantations (5). It has been reported that there are now 470,000 volunteer donors registered with the Turkish Stem Cell Coordination Center. A quarter of this number consists of potential donors between the ages of 18 and 25 years, who are expected to remain active in the system long term (6). Young donors are also preferred because they have fewer medical risks and tend to provide better posttransplant outcomes. As university students are generally young, healthy, educated, open-minded, and active in the community, they represent an important group in stem cell donor recruitment (7).

Various reasons for not wanting to donate stem cells or register with stem cell banks have been reported in the literature. These include lack of knowledge about stem cell donation (8$11)$, health concerns $(8,9,11)$, the idea of compromising bodily integrity (12), fear of pain $(11,13)$, financial issues (13), and fear of complications (13). Few studies have examined these issues in the young population in Turkey. Evaluating young people's knowledge and willingness to donate stem cells will facilitate efforts to recruit more donors by helping to determine the factors that encourage and inhibit them from becoming potential stem cell donors and identify issues that should be emphasized when educating the public. University students comprise an important segment of the young population and can provide valuable insight into other young people in their age group. Simultaneously, considering that health science students will enter the health system in the future and may affect recruiting stem cell donors, it is important to determine their knowledge and perceptions of stem cell donation. This study evaluated health science students' knowledge of stem cell donation, their willingness to become potential stem cell donors, and their perceived incentives and barriers to becoming potential stem cell donors.

\section{Research questions}

1. Do health science students know what stem cell donation is?

2. Do health science students want to be potential stem cell donors?

3. What are health science students' incentives for and barriers to becoming potential stem cell donors?

\section{Methods}

\section{Study design}

This research was designed as a cross-sectional study and was reported according to the Strengthening the Reporting of
Observational Studies in Epidemiology reporting guideline for cross-sectional research (14).

\section{Setting and participants}

The study was conducted with students enrolled in the department(s) of child development, health management, midwifery, nursing, nutrition and dietetics, and physiotherapy and rehabilitation in the health sciences faculty of a university in Turkey. No sampling method was applied. Eligibility criteria were being a registered student in a department listed above, volunteering to participate in the study, and fully completing the study questionnaire. The study population consisted of 766 students. Of these, 559 students were reached during the study period due to absenteeism or leave. Two of the students did not consent to participate, and 16 were excluded because they did not complete the questionnaire thoroughly. Therefore, the study was completed with 541 students $(70.6 \%)$.

\section{Measurement}

Data were collected using a 14-item questionnaire created by the researchers based on relevant literature (8-13,15-22). This questionnaire consisted of three parts. The first part of the questionnaire included six questions about descriptive characteristics such as the student's age, gender, and place of residence before coming to university. The second part of the questionnaire consisted of four questions evaluating the student's knowledge about stem cell donation, and the third part comprised four questions about their willingness to become a potential stem cell donor.

\section{Data collection}

Data were collected using the face-to-face interview method in the classrooms of the faculty of health sciences in October 2019. We contacted the instructor responsible for each course to schedule the date and time of data collection. At the beginning of a class session, we provided information about the study and informed the students that participation was voluntary, they had the right not to answer the questions, and they could withdraw from the study. We also explained to the participants that the information obtained through the study would be anonymized and used for scientific purposes only. After obtaining informed consent from the students who agreed to participate, we distributed the questionnaires. The students were informed that they did not have to write their names on the questionnaire forms. To prevent bias, we asked the students to complete the questionnaire independently, without getting information from any other person or source. We collected the questionnaires immediately after the students completed them. The average time to complete the questionnaire was 10 to 15 minutes.

\section{Statistical Analysis}

IBM Statistical Package for the Social Sciences Statistics for Windows, version 24.0 (Armonk, NY: IBM Corp.) was used for 
data analyses. Descriptive statistics were expressed as number $(n)$, percentage (\%), and median (first quartile-third quartile). Kolmogorov-Smirnov test was used to determine whether continuous data were normally distributed. Chi-square test was used to analyze categorical variables, and Mann-Whitney $U$ test was used to analyze continuous variables with non-normal distribution. $\mathrm{P}<0.05$ was accepted as an indicator of statistical significance.

\section{Ethics}

Ethical approval was obtained from the Cankiri Karatekin University Local Ethics Committee (decision no: 2019/145, date: 23.10.2019). After receiving ethical approval, institutional permission to conduct the study was obtained from the faculty of health sciences of the university. This study was conducted following the principles of the Declaration of Helsinki.

\section{Results}

The descriptive characteristics of the 541 students included in the study are summarized in Table 1 . The average age of the students participating in the study was $19.70 \pm 1.52$ years, $80.8 \%$ were women, $55.3 \%$ came to the university from urban areas, $59.9 \%$ were nursing students, and $56.2 \%$ were first-year students. A family history of cancer was reported by $17.6 \%$ of the students.

Table 2 presents the self-reported knowledge status of the students participating in the study regarding stem cell donation. Most $(80.8 \%)$ of the students stated that they did not know what stem cell donation is, and $88.5 \%$ did not know what the bone marrow bank is. However, $88.4 \%$ stated that they wanted to be informed about the stem cell donation. Of the students who knew what stem cell donation is $(n=104), 60.6 \%$ reported that they obtained this information from online resources and $53.8 \%$ from school.
Of the students who knew what stem cell donation is $(n=104), 5.8 \%$ reported that they were registered as potential stem cell donors, $68.3 \%$ stated that they want to be a potential stem cell donor, $20.2 \%$ were undecided, and $11.5 \%$ did not want to be a stem cell donor (Table 3). The most common reason for wanting to be a potential stem cell donor was the belief that the donation saves lives $(n=71,83.1 \%)$. The most common reason for unwillingness or indecision about being a stem cell donor was the belief that there may be side effects ( $n=33,57.6 \%)$.

\begin{tabular}{|c|c|}
\hline \multicolumn{2}{|l|}{ Characteristic } \\
\hline Age (years), mean $\pm S D$ & $19.70 \pm 1.52$ \\
\hline \multicolumn{2}{|l|}{ Gender, n (\%) } \\
\hline Female & $437(80.8)$ \\
\hline Male & $104(19.2)$ \\
\hline \multicolumn{2}{|l|}{ Pre-university residence, $\mathrm{n}(\%)$} \\
\hline Urban center & $299(55.3)$ \\
\hline Non-urban area & $242(44.7)$ \\
\hline \multicolumn{2}{|l|}{ Department, n (\%) } \\
\hline Nursing & $324(59.9)$ \\
\hline Child development & $59(10.9)$ \\
\hline Midwifery & $57(10.5)$ \\
\hline Nutrition and dietetics & $46(8.5)$ \\
\hline Health management & $32(5.9)$ \\
\hline Physiotherapy and rehabilitation & $23(4.3)$ \\
\hline \multicolumn{2}{|l|}{ Year of education, $\mathrm{n}(\%)$} \\
\hline First & $304(56.2)$ \\
\hline Second & $121(22.4)$ \\
\hline Third & $78(14.4)$ \\
\hline Fourth & $38(7.0)$ \\
\hline \multicolumn{2}{|l|}{ Family history of cancer, $\mathbf{n}(\%)$} \\
\hline Yes & $95(17.6)$ \\
\hline No & $446(82.4)$ \\
\hline
\end{tabular}

\begin{tabular}{|c|c|c|}
\hline & & n (\%) \\
\hline Knows what stem cell donation is & Yes & $104(19.2)$ \\
\hline \multirow{6}{*}{ Source(s) of information about stem cell donation if known $(n=104)^{\star, \#}$} & Internet & $63(60.6)$ \\
\hline & School education & $56(53.8)$ \\
\hline & Television/radio & $34(32.7)$ \\
\hline & Signs/posters/billboards & $18(17.3)$ \\
\hline & Newspaper/magazine & $15(14.4)$ \\
\hline & Relative/friend & $13(12.5)$ \\
\hline \multirow{2}{*}{ Wants detailed information about stem cell donation } & Yes & $478(88.4)$ \\
\hline & No & $63(11.6)$ \\
\hline
\end{tabular}




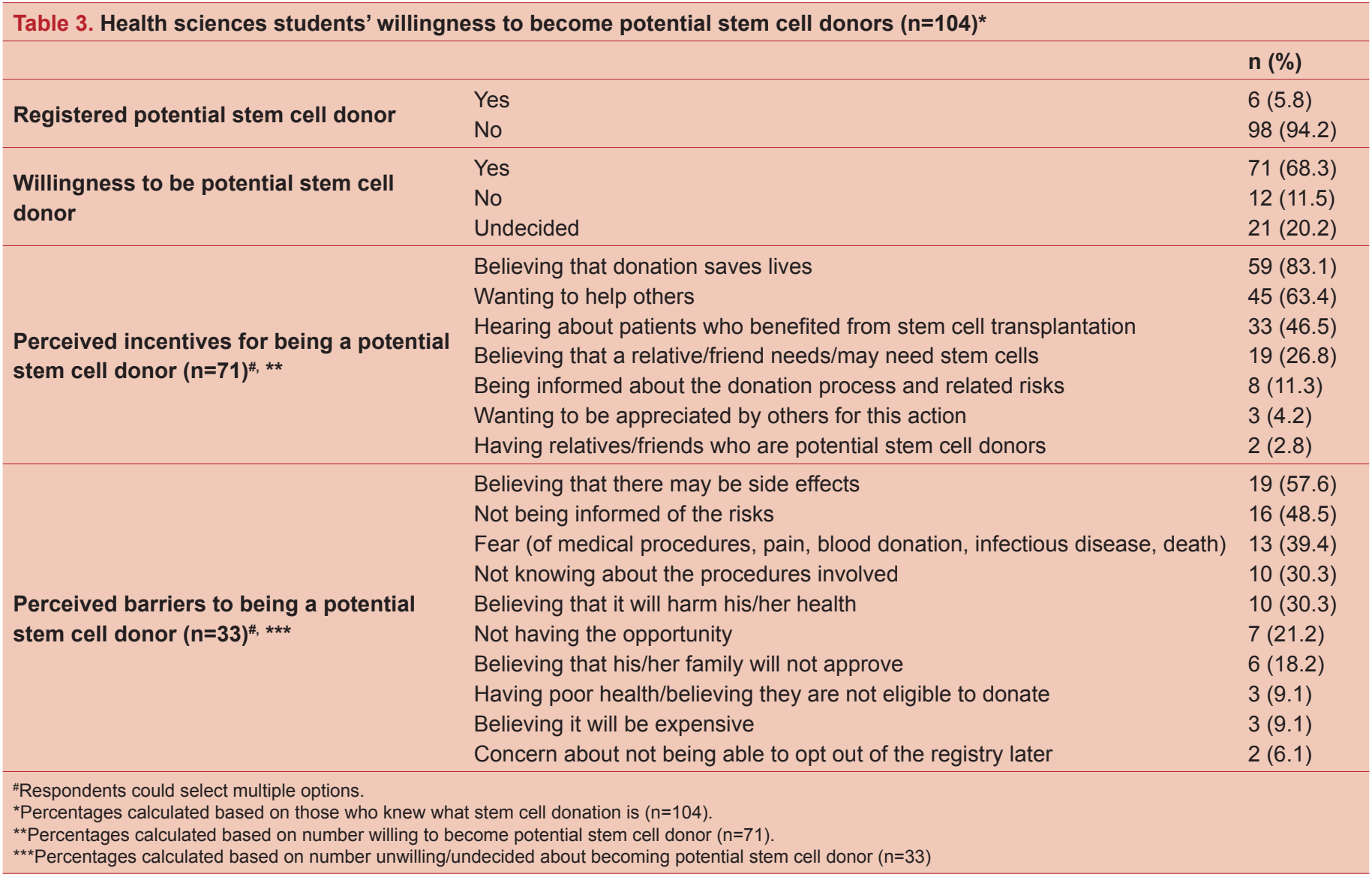

Table 4 shows the comparison of sociodemographic data of students based on their knowledge of stem cell donation. The median age was significantly higher among students who knew what stem cell donation is compared with those who did not ( $z=-$ 4.294, $p<0.001$ ), and significantly fewer first-year students knew what stem cell donation is $\left(X^{2}=32.803, p<0.001\right)$.

Table 5 shows the comparison of descriptive characteristics based on their willingness to become potential stem cell donors. The data were calculated for students who reported that they knew what stem cell donation is $(n=104)$. It was found that older students $(z=-2.971, p=0.003)$ and those in higher classes $\left(X^{2}=8.373, p=0.039\right)$ were more willing to become potential stem cell donors.

\section{Discussion}

This study determined that most health science students did not know what stem cell donation is. Of the students who knew what stem cell donation is $(19.2 \%)$, a small proportion $(5.8 \%)$ were registered with the stem cell bank, but a high proportion $(68.3 \%)$ stated that they wanted to be registered as potential stem cell donors.
Kim and Shin (23) provided hematopoietic stem cell donation education to nursing students and found that knowledge, attitudes, and willingness were better among students who received this education than those who did not. Azzazy and Mohamed (24) also reported improvement in the knowledge and attitudes of nursing students who received education about stem cell therapy. In a study of medical and law students in Turkey, a 15-minute brief education about HSCT increased students' knowledge and awareness (18). These findings indicate that education interventions can raise knowledge among university students in the age group expected to remain in the stem cell donation system for the long term. In this study, most students stated that they did not know what stem cell donation is. These students can be educated to increase their knowledge of stem cell donation.

In this study, the majority $(88.4 \%)$ of the students stated that they want to receive detailed information about stem cell donation. Available literature indicates that information about stem cell donation or stem cell transplantation has been obtained from various sources. Preferred sources of information reported in previous studies included health professionals, the internet, and other media such as television, newspapers, radio $(8,11,12,18)$. 


\begin{tabular}{|c|c|c|c|c|}
\hline & \multicolumn{4}{|c|}{ Knowledge of stem cell donation } \\
\hline & Knows ( $n=104)$ & Does not know $(n=437)$ & Test & $\mathbf{p}$ \\
\hline Age (years), median (Q1-Q3) & $20.0(19-21)$ & $19.0(19-20)$ & $-4.294^{a}$ & $<0.001$ \\
\hline \multicolumn{5}{|l|}{ Gender, n (\%) } \\
\hline Female & $82(18.8)$ & $355(81.2)$ & \multirow{2}{*}{$0.309^{b}$} & \multirow{2}{*}{0.578} \\
\hline Male & $22(21.2)$ & $82(78.8)$ & & \\
\hline \multicolumn{5}{|l|}{ Pre-university residence, $\mathrm{n}(\%)$} \\
\hline Urban center & $58(19.4)$ & $241(80.6)$ & \multirow{2}{*}{$0.013^{b}$} & \multirow{2}{*}{0.909} \\
\hline Non-urban area & $46(19.0)$ & $196(81.0)$ & & \\
\hline \multicolumn{5}{|l|}{ Department, $\mathbf{n}(\%)$} \\
\hline Nursing & $73(22.5)$ & $251(77.5)$ & \multirow{6}{*}{$8.032^{\mathrm{b}}$} & \multirow{6}{*}{0.155} \\
\hline Child development & $8(13.6)$ & $51(86.4)$ & & \\
\hline Midwifery & $7(12.3)$ & $50(87.7)$ & & \\
\hline Nutrition and dietetics & $10(21.7)$ & $36(78.3)$ & & \\
\hline Health management & $4(12.5)$ & $28(87.5)$ & & \\
\hline Physiotherapy and rehabilitation & $2(8.7)$ & $21(91.3)$ & & \\
\hline \multicolumn{5}{|l|}{ Year of education, $\mathrm{n}(\%)$} \\
\hline First & $39(12.8)$ & $265(87.2)$ & \multirow{4}{*}{$32.803^{b}$} & \multirow{4}{*}{$<0.001$} \\
\hline Second & $22(18.2)$ & $99(81.8)$ & & \\
\hline Third & $27(34.6)$ & $51(65.4)$ & & \\
\hline Fourth & $16(42.1)$ & $22(57.9)$ & & \\
\hline \multicolumn{5}{|l|}{ Family history of cancer, $\mathbf{n}(\%)$} \\
\hline Yes & $24(25.3)$ & $71(74.7)$ & \multirow{2}{*}{$2.707^{b}$} & \multirow{2}{*}{0.100} \\
\hline No & $80(17.9)$ & 366 (82.1) & & \\
\hline
\end{tabular}

\begin{tabular}{|c|c|c|c|c|}
\hline & \multicolumn{4}{|c|}{ Willingness to become potential stem cell donor } \\
\hline & Willing ( $n=71)$ & $\begin{array}{l}\text { Unwilling/undecided } \\
(\mathrm{n}=33)\end{array}$ & Test & $\mathbf{p}$ \\
\hline Age (years), median (Q1-Q3) & $20.0(20-21)$ & $19.0(19-20)$ & $-2.971^{a}$ & 0.003 \\
\hline \multicolumn{5}{|l|}{ Gender, n (\%) } \\
\hline Female & $59(72.0)$ & $23(28.0)$ & \multirow{2}{*}{$2.426^{b}$} & \multirow{2}{*}{0.119} \\
\hline Male & $12(54.5)$ & $10(455)$ & & \\
\hline \multicolumn{5}{|l|}{ Pre-university residence, $\mathrm{n}(\%)$} \\
\hline Urban center & $42(72.4)$ & $16(27.6)$ & \multirow{2}{*}{$1.040^{\mathrm{b}}$} & \multirow{2}{*}{0.308} \\
\hline Non-urban area & $29(63.0)$ & $17(37.0)$ & & \\
\hline \multicolumn{5}{|l|}{ Department, n (\%) } \\
\hline Nursing & $52(71.2)$ & $21(28.8)$ & \multirow{2}{*}{$0.993^{b}$} & \multirow{2}{*}{0.319} \\
\hline Other" & $19(61.3)$ & $12(38.7)$ & & \\
\hline \multicolumn{5}{|l|}{ Year of education, n (\%) } \\
\hline First & $21(53.8)$ & $18(46.2)$ & \multirow{4}{*}{$8.373^{b}$} & \multirow{4}{*}{0.039} \\
\hline Second & $18(81.8)$ & $4(18.2)$ & & \\
\hline Third & $18(66.7)$ & $9(33.3)$ & & \\
\hline Fourth & $14(87.5)$ & $2(12.5)$ & & \\
\hline \multicolumn{5}{|l|}{ Family history of cancer, $\mathbf{n}(\%)$} \\
\hline Yes & $19(79.2)$ & $5(20.8)$ & \multirow{2}{*}{$1.710^{\mathrm{b}}$} & \multirow{2}{*}{0.191} \\
\hline No & $52(65.0)$ & $28(35.0)$ & & \\
\hline
\end{tabular}


In this study, we determined that most of the students who knew about the stem cell donation obtained this information via the internet, formal education, and television/radio. These findings suggest that using these information sources is effective in education aiming to inform the public. Reliable information about stem cell donation can be disseminated through the education provided by health professionals, detailed study of the subject in schools, the inclusion of educational content on television/radio, and especially the internet and social media, which are widely used by the new generation. In this way, awareness can be raised among the young population, increasing their likelihood of registration and enlarging the donor pool. Simultaneously, students who will work as health professionals after graduation should have enough knowledge and positive attitudes about stem cell donation. This will enable them to serve as a reliable source of information that can support the community in their decisions about becoming stem cell donors.

Kwok et al. (11) reported that individuals with more knowledge about HSCT were more likely to be hematopoietic stem cell donors. In contrast, in this study, many students who knew about the stem cell donation were willing to donate, but few were registered as potential stem cell donors. This raises the question of why these students were not registered despite their knowledge and willingness. Possible reasons may be a lack of motivation, lack of chance, and easy access to a registration site. We predict that more willing individuals can be registered in the donor pool by increasing students' motivation, organizing donor campaigns, and increasing the accessibility of the mobile blood donation team. However, the answer to this question should be investigated with a qualitative study.

Knowing the factors that encourage people to become a stem cell donor is important for expanding the potential donor pool (17). The main incentives stated by the students in this study who knew about the stem cell donation included the belief that donation saves lives, the desire to help others, and having heard about patients who benefited from stem cell transplantation. Suluhan et al. (12) also determined that the idea of saving lives was one of the main reasons for wanting to be a stem cell donor. In a study by Aurelio et al. (15), helping patients was a participant' primary motivators for registering as donors. Bart et al. (10) found that the prospect of saving lives, solidarity with fellow humans, and the prospect of increasing patients' chances of recovery were the main incentives for registering with stem cell banks. Emphasizing these motivating factors in the education provided to university students can increase their willingness, thereby helping to increase the number of potential stem cell donors.

The students in this study stated concerns about possible side effects, lack of knowledge about the risks, and fear (of medical procedures, pain, blood donation, infectious diseases, or death) as the main reasons for their unwillingness or indecision about being a potential stem cell donor. Barriers to registration reported in other studies have included pain, health concerns, fear of complications, and lack of information $(8,10,11)$. These perceived barriers to being a potential stem cell donor are issues that should be focused on and addressed in the education provided to students. Additionally, it may be helpful to include information about common misperceptions and barriers to registration in all forms of educational material containing information about stem cell donation.

This study found that older students more frequently stated that they knew what stem cell donation is, while new students stated this less frequently. We also observed a greater willingness to be potential stem cell donors among older and higher classes. This finding may be attributable to the accumulation of theoretical and practical knowledge as they progress in their program in the faculty of health sciences.

\section{Study Limitations}

This study has several limitations. One of these is that the study was conducted with health science students of a single university. Therefore, the results obtained in this study cannot be generalized to society at large. Another limitation is that our results are based on an analysis of quantitative data. Qualitative studies are needed for a more comprehensive evaluation of experiences and opinions related to stem cell donation. Moreover, the students' knowledge and willingness regarding stem cell donation were evaluated using a questionnaire we prepared based on a literature review. Valid and reliable scales measuring awareness, knowledge, attitudes, and willingness about stem cell donation are needed to obtain more quantitative data on this subject.

\section{Conclusion}

This study determined that most health science students did not know what stem cell donation is. Moreover, many students who knew about the stem cell donation expressed willingness to become potential stem cell donors, but very few of them were registered with the stem cell bank. Older students and those in higher classes more frequently knew what stem cell donation is and expressed greater willingness to be potential donors. Our study sample included students from different geographical regions of Turkey and different cultures. Therefore, we believe that our results offer insight into the awareness and attitudes of young people in this age group. Modifying health science curricula to address the stem cell donation in more detail may improve knowledge in these students, who will join the health workforce after they graduate. Ensuring that health professionals know stem cell donation and transplantation will also facilitate the provision of reliable information to the community and registration of donors. The contents of educational and promotional materials related to stem cell donation should be 
developed considering the factors that encourage and hinder individuals from donating stem cells.

\section{Acknowledgment}

We would like to thank the students who participated in this study.

\section{Ethics}

Ethics Committee Approval: Ethical approval was obtained from the Cankiri Karatekin University Local Ethics Committee (decision no: 2019/145, date: 23.10.2019).

Informed Consent: Informed consent was obtained from the students.

Peer-review: Externally and internally peer-reviewed.

\section{Authorship Contributions}

Concept: D.B., F.İ.Ç., Design: D.B., F.İ.Ç., Data Collection or Processing: D.B., F.İ.Ç., Analysis or Interpretation: D.B., F.I.Ç., Literature Search: D.B., F.I.Ç., Writing: D.B., F.I.Ç.

Conflict of Interest: No conflict of interest was declared by the authors.

Financial Disclosure: The authors declared that this study received no financial support.

\section{References}

1. Cady J, Jackowski JA. Cancer. In: Medical Surgical Nursing Assessment and Management of Clinical Problems. 8th ed. United States of America: Elsevier Mosby; 2011:291.

2. Türkmen B, Gürsel $O$, Atay $A A$, et al. Immunophenotypic detection of umbilical cord blood stem cell, lymphocyte and lymphocyte subpopulations. Gulhane Med J. 2008;50:261266.

3. Galanis PA, Sparos LD, Katostaras T, Velonakis E, Kalokerinou A. Factors that influence Greeks' decision to register as potential bone marrow donors. Transplant Proc. 2008;40:12711274.

4. Hasçuhadar M. TÜRKÖK. The Turkish Society of Hematology 9th National Bone Marrow Transplantation and Stem Cell Therapies Congress Book. Antalya; 2016;62.

5. Hasçuhadar M. TÜRKÖK'de Son Durum. The Turkish Society of Hematology 10th National Bone Marrow Transplantation and Stem Cell Therapies Congress Book. Antalya; 2018;3637.

6. Öztürk M. TÜRKÖK'de Son Durum. The Turkish Society of Hematology 11th National Bone Marrow Transplantation and Stem Cell Therapies Congress Book. Antalya; 2019;47-49.

7. Varghese ST, Hem M. Peripheral blood stem cell donation awareness among college students. International Journal of Science, Technology and Management. 2015;4:1-5.

8. Abdrbo A, Hassanein S, Albajhan G, Alsabi F. Factors influencing hematopoietic stem cell donation. IOSR Journal of Nursing and Health Science. 2017;6:54-61.

9. Bagcivan G, Ozen N, Bayrak D, Cinar FI. Does being a cancer patient or family caregiver of a cancer patient affect stem cell donation awareness? Asia Pac J Oncol Nurs. 2020;7:36-43.
10. Bart T, Volken T, Fischer $\mathrm{Y}$, Taleghani BM. Giving blood and enrolling on the stem cell donor registry: ranking of obstacles and motives in Switzerland. Transfus Med Hemother. 2014;41:264-272.

11. Kwok J, Leung E, Wong W, et al. Factors influencing hematopoietic stem cell donation intention in Hong Kong: a web-based survey. Ann Transplant. 2015;20:604-613.

12. Suluhan D, Eker I, Yıldız D, et al. Determination the knowledge, attitude and motivation of voluntary blood donors about being hematopoietic stem cell donor. TAF Prev Med Bull. 2016;15:512-517.

13. Vasconcellos A, Nunes A, Feller E. Knowledge, attitudes, and behaviors regarding the bone marrow registry among college and medical students in Rhode Island. Med Health R I. 2011;94:302-305.

14. von Elm E, Altman DG, Egger M, et al. The strengthening the reporting of observational studies in epidemiology (STROBE) statement: guidelines for reporting observational studies. J Clin Epidemiol. 2008;61:344-349.

15. Aurelio MT, Aniasi A, Haworth SE, et al. Analysis of the motivation for hematopoietic stem cell donation. Transplant Proc. 2011;43:981-984.

16. Glasgow ME, Bello G. Bone marrow donation: factors influencing intentions in African Americans. Oncol Nurs Forum. 2007;34:369-377.

17. Hyde MK, McLaren PJ, White KM. Identifying belief targets to increase bone marrow registry participation among students who have never donated blood. Psychol Health Med. 2014;19:115-125.

18. Kaya Z, Gültekin KE, Demirtaş OK, Karadeniz D, Çalapkulu Y, Tap Ö. Effects of targeted education for first-year university students on knowledge and attitudes about stem cell transplantation and donation. Exp Clin Transplant. 2015;13:7681.

19. Laver JH, Hulsey TC, Jones JP, Gautreaux M, Barredo JC, Abboud MR. Assessment of barriers to bone marrow donation by unrelated African-American potential donors. Biol Blood Marrow Transplant. 2001;7:45-48.

20. Narayanan P, Wolanskyj A, Ehlers SL, et al. Medical students knowledge, familiarity, and attitudes towards hematopoietic stem cell donation: stem cell donation behaviors. Biol Blood Marrow Transplant. 2016;22:1710-1716.

21. Onitilo AA, Lin YH, Okonofua EC, Afrin LB, Ariail J, Tilley BC. Race, education, and knowledge of bone marrow registry: indicators of willingness to donate bone marrow among African Americans and Caucasians. Transplant Proc. 2004;36:32123219.

22. Sikora A, Wiorkowski K, Szara P, Drabko K. Knowledge and attitude of Lublin universities students' toward the opportunity of becoming unrelated bone marrow donor. Folia Med Cracov. 2014;54:27-33

23. Kim M, Shin M. Effect of educational program on knowledge, attitude, and willingness of nursing students for hematopoietic stem-cell donation. Int $\mathrm{J}$ Environ Res Public Health. 2019;16:3696.

24. Azzazy HM, Mohamed HF. Effect of educational intervention on knowledge and attitude of nursing students regarding stem cells therapy. IOSR Journal of Nursing and Health Science. 2016;5:75-80. 